\title{
Intellectual Capital, Competitive Advantage, Financial Performance And Company Value Among Banking Industries In Indonesia
}

\author{
Windu Mulyasari \\ Doctoral Program of Trisakti University \\ Etty Murwaningsari \\ Doctoral Program of Trisakti University
}

\begin{abstract}
Intangible asset in the form of intellectual capital becomes one of the factors that affect the performance and value of the company. Intellectual capital provides value added to the company, which encourages the production process and competitiveness. The progress of business processes has implications for the increase in company profits responded positively by the market. The intellectual capital issue is interesting to study, especially regarding its implications for company value. Intellectual capital influences the value of the company through competitive advantages that encourage the increase of company performance. The main objective of this study is to observe the effect of intellectual capital on company value. The author also hypothesized the mediating effect on the relationship, namely competitive advantage and financial performance. The study samples were taken from data on the Indonesia stock exchange, especially in the banking sector in Indonesia for the period of 2012-2015. The study results showed that there was an effect of intellectual capital on company value and that effect was mediated by competitive advantage and financial performance. Competitive advantage was also found to have an effect on company value and the relationship was mediated by company performance.
\end{abstract}

Keywords: Intellectual Capital, Competitive Advantage, Company Performance, Company Value.

\section{BACKGROUND}

Study that explores factors that influence the company's financial performance and the implications of financial performance is still an interesting subject. Various factors that influence financial performance and it's implications continue to be explored. In this study, the implications of financial performance were considered to increase the company value. Assets have a major influence in forming a financial statement that has implications for financial performance and affects the company value. Banking performance is important to note since banking as an intermediary institution plays an important role in the economy of a country. Company value is an indicator of the company business development.

Company value describes the condition of the company. Company value is defined as a certain condition achieved by the company that provides an overview of public trust towards the company and a description of the company's future prospects. Company value reflects the value of company assets such as company securities such as shares. Increasing company value means maximizing the prosperity of shareholders.

Bank is also called an agent of trust and agent of development, because it is responsible for maintaining public trust in the main activities that are carried out, namely, saving and 
channeling funds. The bank as an agent of development has a role to mediate economic actors to gain access to funds for investment, distribution, production and consumption activities. The ability of banks to manage capital aspects and assets held to obtain profits is an indicator of banking financial performance.

The position of the bank is very important in a country as one of the pillars of the economy, and the stability in the banking business is highly demanded. The economic crisis that occurred in Indonesia has caused economic chaos and influenced the level of public trust. This condition demands the banking sector to regain public image and trust towards banking services. The banking sector is required to improve the performance and operational health of its business.

The improvement of financial performance can be viewed from various aspects. Asset is one of the aspects that affect banking financial performance. Banking is an industry that always innovates its products and services and is also based on intellectuality. Banking highly emphasizes knowledge and flexibility to achieve business success. For the banking industry, the ability to compete lies not only in ownership of tangible assets but also in ownership of intangible assets. Intangible assets can take the form of innovations carried out by companies, information systems owned, ways of managing organizations and human resources that are utilized for organizations. For the financial services industry such as banks, the elements of intangible assets are very important. Starovic (2003) states that business activities increasingly direct the attention to the importance of intangible assets, in this case is the knowledge assets. Knowledge is an asset that can drive the development of a business. The approach to valuing and measuring intangible assets uses intellectual capital.

According to Stewart (1997), intellectual capital is a set of knowledge that shapes intellectual property and is also an experience used to create wealth. Intellectual capital becomes a focus on various fields such as management studies, information technology, sociology, and other important field is accounting (Petty, 2000). Today's business activities recognize that intellectual capital is a very valuable asset. Companies must have awareness to develop strategies in order to compete in the market and become more sustainable. Sustainable also in the sense of the capability of the resources owned by the company which in principle is based on intellectual capital in order to create value added. This will produce an efficient and effective company performance so that it can produce superior products. Superior products can compete in the market and boost sales and finally followed by increased company profits.

Intellectual capital, which is part of intangible assets, is difficult to be clearly identified in a company. An indirect assessment of intellectual capital is suggested by Pulic (1999) to assess the intellectual ability of a company by using efficiency measures of value added. The recommended assessment model is Value Added Intellectual Coefficient (VAIC). The VAIC method can provide various information on creating efficiency for the value of tangible assets and intangible assets of the company. This approach is considered relatively easy and is widely used in various studies. This approach is also possible to be applied because it uses the accounts contained in the company's financial statements.

Many previous studies have used the VAIC assessment method to assess VAIC's intellectual capital on the company's financial performance. A study conducted by by Riahi and Belkaoui (2003) on multinational companies in the United States of America proved the effect of intellectual capital on the company's financial performance. Rodriguez (2011) found an evidence of a relationship between the components of intellectual capital and hospital performance. The components of intellectual capital are human capital, structural capital, and relation capital. The three elements of intellectual capital were found to influence the 
capability of innovation within the company. Chen, et al. (2005) analyzed the relationship between intellectual capital and the market to book value and financial performance among companies in Taiwan. The results of his study showed that there was a positive effect of intellectual capital on the company's financial performance. Ulum (2008) found evidence of the effect of intellectual capital on the financial performance of banking companies in Indonesia.

However, the management of intellectual capital does not only stop at its direct effect on company performance. One challenge on the development of the banking industry is that it must be able to manage intellectual capital to provide value added to the business. The development of labor globalization, marked by the establishment of the ASEAN Economic Community in 2015 by promoting the character of a single market and regional production base, raised awareness of banking industries on the importance of managing human capital that has value added to the company. The banking industries must have a competitive advantage in order to create value added. This means that a company should have something different from things owned by the competitors. Management of intellectual capital must be able to increase competitive advantage and influence banking performance. Porter (1980) states that competitive strategies can produce competitive advantages by producing superior products with lower production costs compared to competitors. Resource-based theory (RBT) was used as a basis to explain the competitive advantage variable in this study. Competitive advantage explains the creation of abnormal profits or above average returns using specific aspects of the company (Lin and Huang, 2011).

The study aims to obtain empirical evidence of the effect of intellectual capital on company value in the banking sector, which is mediated by competitive advantage and financial performance. This issue is still an important topic to study, because the disclosure of intellectual capital is considered to have the usefulness of information for decision making for the users of financial statements, especially stakeholders. The selection of study samples in the banking industry referred to previous studies namely Kamath (2006), Mavridis (2005), and Firer and William (2003). The banking industry was chosen because this sector has a high intensity and interest in intellectual capital according to the Global Industry Classification Standard (GICS). According to Kubo and Saka, 2002 the intellectual aspects of banking employees as a whole are more homogeneous than other industries. In addition, the banking industry is a vital industry and has a significant role in the economic development of a country (Rafinda, 2011).

This study aims to obtain empirical evidence of the effect of intellectual capital on company value, which is mediated by competitive advantage and financial performance. Nixon Kamukama, et al. (2011) in his study in Uganda found that competitive advantage was the mediation variable on the relationship between intellectual capital and financial performance. Rodriguez (2004) in his study stated that the three elements of intellectual capital influenced the capability of innovation in the company. The key of implementing innovation capabilities can be measured through the company's R\&D expense. R\&D variable was used since it has a close relationship with profit. Profit optimization as a company goal requires R\&D planning in the company's strategy.

\section{LITERATUR REVIEW AND DEVELOPMENT OF HYPOTHESIS}

The success of a company in generating profits can be assessed from financial performance indicators. Financial performance can show the effectiveness and efficiency of an organization in its efforts to achieve company goals. The company's financial performance indicators can be used to show the company's ability to carry out its production activities. The company's ability to become more competitive will be realized if it has the advantage of resources, both tangible 
assets and intangible assets. The company must also have the ability to manage its resources effectively. Asset ownership and the company's ability to manage assets and create unique competencies can be a competitive advantage for the company.

Identifying potential key resources within the company is a key component to achieve competitive advantage. The key resources are assets, capabilities, organizational processes, attributes, and knowledge controlled by the company. The owned resources drive the company to improve its efficiency and effectiveness. Resource based theory is used to provide an explanation of the criteria for identifying key resources in the company. The first criterion is that key resources are owned by the company and must be able to support the services to meet customer needs. Second, resources are assets that are owned in limited or rare quantities and are not easily replicated. Resources become difficult to imitate if they are physically unique and it takes a long time and a lot of cost to be obtained. Third, resources are used to obtain maximum profit for the company. And finally the existing resources have durability, because they have a low depreciation rate and even experience appreciation, such as brand, reputation awareness, and company culture.

Edvinsson (1997) states that intellectual capital is the ownership of knowledge, special experience, organizational technology, relationships with consumers, and professional expertise. These characteristics are categorized into three components of intellectual capital, namely: human capital, internal capital, and relation capital. Human capital relates to the education and expertise of employees who can improve professionalism or the "extent of professionalism" (Vergauwen et al, 2007) and the existence and effectiveness of employees to improve company productivity. Human capital is a bloodlife in intellectual capital. Humans are born with thinking skills and special skills and competencies in work. Innovation and improvement are born for the products and services produced through this human capital.

Structural capital adalah kemampuan perusahaan untuk mengolah kinerja Structural capital is the company's ability to process intellectual performance and business performance optimally. This capability can support the formation of employee business structures. Structural capital is intellectual capital which is internally developed to capture the effectiveness of the company's policies and business processes, maintain a conducive working environment, and create innovation from the study and development department (Petty and Guthrie, 2000). Structural capital can be based on strategies, patents and trademarks.

Customer capital is a relationship between a company and a third party such as consumers and suppliers (Bontis, 2001). Sawarjuwono and Kadir (2003) state that customer capital is the way in which a company fosters harmonious relationships with its partners or external parties, such as suppliers, customers, government and society. The quality of good relationships and the ability to create new customers are key factors that provide success for a company.

This study used resources based theory to explain that management must obtain, acquire, and manage intellectual capital efficiently and effectively by using unique ways to create competitive intellectual capital. Characteristics as unique resources can be used to create competitive advantages so that they can create value added for the company. The value added is in the form of performance improvement and providing a competitive advantage for the company.

Bontis (1998) initiated a study on intellectual capital by exploring relationships between the components of intellectual capital, namely human capital, customer capital, and structural capital. The study used VAIC to assess intellectual capital.

H1 : Intellectual Capital has a positive effect on Company. 
Firer and William (2003) investigated the effect of intellectual capital on performance. The study result provided an empirical evidence that physical capital had a significant effect on company's performance and it was the most significant factor in South Africa. Study conducted by Chen et al. (2005) obtained an evidence that there was an effect of intellectual capital on market value and company financial performance both in the present and future. Investors were also proven to give different valuation possibilities on the three components of VAIC (i.e. physical capital, human capital, and structural capital). Tan, et al. (2007) who investigated 150 companies on the Singapore stock exchange, obtained an evidence that intellectual capital was positively related to the performance of the company in the present and future.

A study conducted by Chen et al. (2005) and Abdolmohammadi (2005) showed a contribution of intellectual capital to the improvement of company's financial performance. Other studies also obtained similar result on the effect of intellectual capital on company's ROA (Chen et al., 2005; Ghosh \& Mondal, 2009; Zeghal \& Maaloul, 2010). Siddiq (2013) found an evidence that the company's ability to manage the performance of intellectual capital could improve the performance of manufacture companies in Indonesia.The ability of companies to manage the components of intellectual capital could have an effect on the company's assets. Based on the statement above, a hypothesis can be arranged as follows:

H2: Intellectual Capital has a positive effect on Financial Performance.

The competitive advantage of the company comes from internal part the company in the form of intellectual capital. Competitive advantage influences the ability of companies to create excellence through the use of resources that enable companies to grow and develop. The ability to utilize intellectual capital effectively and efficiently can affect a company's ability to innovate and create products so that the company can still exist in industrial competition. This will encourage companies to continue to develop resources in the form of intellectual capital in order to be superior in industrial competition to improve company's performance.

Utari (2013) observed the relationship between intellectual capital and competitive advantage in manufacture companies, the results supported the consistency of resource based theory. The theory states that companies that can maintain their competitive advantage have the ability to create value added for the company and ultimately for stakeholders by managing their VRIN strategic assets efficiently. Hsu and Fang (2009) provided evidence on the effect of Intellectual Capital on competitive advantage. The study results indicated that relational capital and structural capital had a positive impact on competitive advantage. Relational capital was the dominant factor in the component of intellectual capital in Taiwanese design companies, while structural capital was the second factor and human capital was the third factor.

In relation to competitive advantage, the following hypothesis can be proposed:

H3 : Intellectual Capital has a positive effect on competitive advantage.

Diwaf et al (2012) observed the relationship between Intellectual Capital and the company's market value. The results of the study showed that each component of Intellectual Capital had a different effect on the company's market value. VACA had a statistically significant positive effect on market value. VAHU had a negative and not significant effect on market value. STVA had a positive and not significant effect on market value. The study results indicated that the relationship between intellectual capital and company value was inconsistent. This study explored the mediation effect between those relationships. 
Harahap (2014) in his study stated that there was a relationship between intellectual capital with company value and financial performance. Financial performance was proven to mediate the relationship between intellectual capital and company value. Pramelasari's study (2010) proved that there was different effect of each component of intellectual capital on the company's market value and the company's financial performance.

H4 : The relationship between Intellectual Capital and Company Value is mediated by Financial Performance.

In a study conducted by Kamukama et al (2011) obtained anevidence that there was a mediating effect of competitive advantage on the relationship between intellectual capital and company performance. Rodriguez (2004) in his study found a relationship between the components of intellectual capital namely human capital, structural capital, and relation capital and the capabilities of innovation within the company. The key to implementing innovation capabilities is assessment through R\&D expense in the company.

According to $\mathrm{Wu}$ (2013), the capability of innovation has the effect of bringing intellectual capital to be more effective in improving financial performance. Intellectual has a role to spur resources, especially intangible resources. These resources are useful for increasing innovation by winning market competition in the industry. This is what will lead to financial performance improvement. Based on the statement above, a hypothesis can be arranged as follows:

H5 : Competitive advantage mediates the relationship between Intellectual Capital and Company Performance.

Competitive advantage is the company's ability to create value with the management of company resources. According to Porter (1980), competitive advantage is the ability of companies to get a periodic return on investment above the industry average. Competitive advantage is the company's strategy to innovate differently from its competitors in order to win market share. Based on the statement above, a hypothesis can be arranged as follows:

H6 : ompetitive advantage mediates the relationship between Intellectual Capital and Company Value.

Figure 1

Conceptual Framework

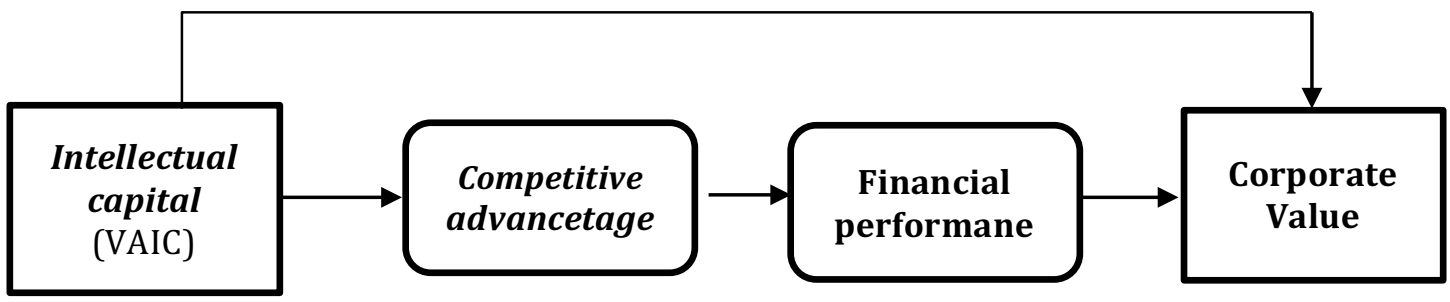

\section{RESEARCH METHODS}

\section{Population and Samples}

This study was conducted on banking sector companies listed on the Indonesia Stock Exchange (IDX) in the period of 2012-2015. Banking companies that were intended as the study samples were chosen with the following criteria:

1. Banking companies listed on the Indonesia Stock Exchange during 2012-2015

2. Banking companies that published financial statements during 2012-2015

3. Companies with positive earnings in one period were included.

Companies with negative earnings were not included as the sample in this study because it was assumed that if a banking company experienced a loss or had negative earnings it meant that 
the banking company had poor financial performance. Companies with good financial performance means that they are able to generate optimal profits, since financial performance can be seen from the operating income earned.

The data used in this study were financial statements of banking companies listed on the Indonesia Stock Exchange within the period of 2012-2015.

\section{Operational Variables}

Intellectual capital in this study was assessed using VAIC method (Pulic, 2000). The operationalization of intellectual capital variable was as follows:

VA= INPUT (Operating income \& non-operating income) - OUTPUT (Total expenses except employee expenses)

$$
\begin{aligned}
& \text { VAHU }=\frac{\text { Value Added }}{\text { B.gaji+tunjangan }} \\
& V A C A=\frac{\text { Value Added }}{\text { Equity }+ \text { Net } \text { Profit }} \\
& \text { STVA }=\frac{(\text { Value Added-salary expense }+ \text { subsidy for employees })}{\text { Value Added }} \\
& \text { VAIC }=\text { VACA+VAHU+STVA }
\end{aligned}
$$

Company value was assessed using price-to-book value (PBV). PBV is a market ratio that is used to assess stock price performance against the book value (Ang, 1997). Meanwhile, according to Brigham and Houston (2011), PBV is the result of a comparison between stock price and stock book value. The book value can be formulated as follows (Weston dan Bringham):

$P B V=\frac{\text { Share Equity }}{\text { Number of outsanding shares }}$

Financial performance was proxied using the return on asset (ROA) value. The assessment of the competitive advantage variable in this study used the R\&D expense which was made into logarithm. The key to implementing innovation capabilities is assessment through R\&D expense in the company.

The equation model to test the hypothesis in this study is as follows:

$$
\mathrm{PBV}=\alpha+\beta_{1} \mathrm{VAIC}+\beta_{2} \mathrm{R} \& \mathrm{D}+\beta_{3} \mathrm{ROA}+\varepsilon
$$

Hypothesis test on the mediation variables was conducted by looking at the direct and indirect effects of the variables studied. Test on the mediation variables used path analysis.

\section{RESULTS}

The test results on the study data illustrated that the company value variable had a minimum value of 0.120 , a maximum value of 5.7, and a mean of 1.59730. Financial performance with a ratio of Return on Assets had a minimum value of 0.0020 . The maximum value of ROA was 0.0514 . The mean of ROA was 0.021572 with a standard deviation of 0.0104305 . The Intellectual Capital variable with the VAIC indicator had the lowest value of 1.38 and the maximum value of 5.08. The mean of VAIC was 3.0833 with a standard deviation of 0.84578 . 
Mediation variables with $R \& D$ expense Log had a minimum value of 2,393 . The maximum value of R\&D expense Log was 5.841. The mean of R\&D expense Log was 4.51645 with a standard deviation of 0.728701 .

Table 1

Descriptive Statistic

\begin{tabular}{lcccc}
\hline & PBV & ROA & VAIC & R\&D \\
\hline Minimum & 0,120 & 0,0020 & 1,3800 & 2,3927 \\
Maksimum & 5,700 & 0,051 & 5,0800 & 5,8406 \\
Mean & 1,59730 & 0,02157 & 3,083300 & 4,516451 \\
Std. Deviation & 1,077203 & 0,010431 & 0,8454776 & 0,7287005 \\
\hline
\end{tabular}

\section{Hypothesis Test Results}

Hypothesis 1 states that company value is influenced by Intellectual Capital. Table 2 shows the test result for the regression equation model 1 . The regression equation test 1 showed that the R2 value was 0.234 , so the company value was explained at $23.4 \%$ by the financial performance, Intellectual Capital and competitive advantage variables. The $\mathrm{F}$ test value showed significant results, meaning that the regression model 1 was good. The test results showed that Intellectual Capital and competitive advantage had no effect on company value. Meanwhile, financial performance had a positive effect on company value. The test results proved that the effect of Intellectual Capital on company value was influenced by other variables that mediated the relationship. Similarly, competitive advantage also indirectly affects the company value.

Table 2

Hypothesis 1 Test Results

\begin{tabular}{lc}
\hline & \multicolumn{1}{c}{ Hipotesis $\mathbf{1}$} \\
& $\mathbf{P B V}=\boldsymbol{\alpha}+\boldsymbol{\beta}_{\mathbf{1}}$ VAIC $+\boldsymbol{\beta}_{\mathbf{2}} \mathbf{R} \boldsymbol{\&} \mathbf{D}+\boldsymbol{\beta}_{\mathbf{3}} \mathbf{R O A}+\boldsymbol{\varepsilon}$ \\
\hline R Square & 0,257 \\
Adjusted R Square & 0,234 \\
Std. Error of the Estimate & 0,942721 \\
F & 11,087 \\
& $(0,000)^{* * *}$ \\
constant & $-0,359(0,558)$ \\
Financial Performance & $43,321(0,001)^{* * *}$ \\
Intellectual Capital & $0,60(0,710)$ \\
Competitif Advantage & $0,185(0,196)$ \\
\hline
\end{tabular}

Mediation test was carried out using path analysis. The test results as shown in table 2 proved that there was a mediating effect on the relationship between Intellectual Capital and company value. This study observed the competitive advantage and financial performance variables as the mediating variables on the relationship. The results of the path analysis test can be seen in table 3 . 
Table 3

Mediation Test Results

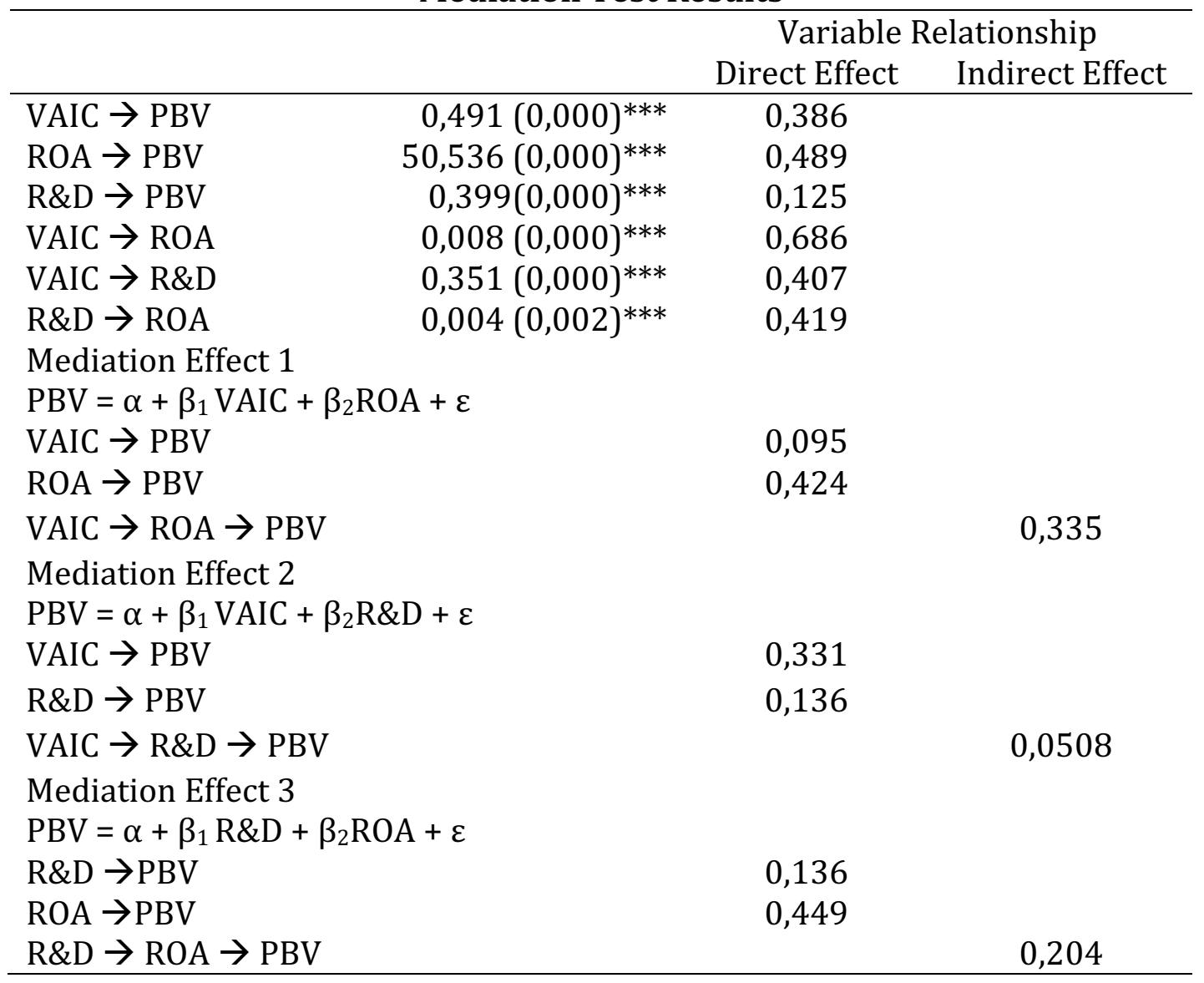

The test results in this study proved the mediating effect on the relationship between intellectual capital and company value. The direct effect on the relationship between intellectual capital and company value was 0.095, and the indirect effect through financial performance was 0.335 . The test results proved that financial performance mediated the relationship between intellectual capital and company value.

This study also hypothesizes the mediating effect of competitive advantage on the relationship between intellectual capital and company value. The results of path analysis test proved that the direct effect on the relationship between intellectual capital on company value was 0.331 , and indirect effect through competitive advantage was lower at 0.0508. Thus, competitive advantage was not proven to mediate the relationship between intellectual capital and company value.

The hypothesis in the study states that financial performance mediates the relationship between competitive advantage and company value. The test results with path analysis found that the direct effect on the relationship between competitive advantage and company value of 0.136 was lower than the indirect effect through financial performance of 0.204 .

This study proved that intellectual capital had an effect on financial performance and company value. The effect of intellectual capital on company value was mediated by financial performance. That is, the management of intellectual capital in companies could improve financial performance and ultimately encouraged the growth of company value. The competitive advantage owned by the company is one of the factors that can improve banking financial performance and increase company value. 
The analysis result showed that go public banking companies in Indonesia have been able to create value added to generate greater profits by utilizing capital employed. Banking companies use the value of their employees' knowledge to generate company wealth. With the expertise and knowledge of employees, companies can create the best solutions so that the company value may increase. Banking companies in Indonesia use their intellectual capital to carry out routine activities and develop good structures to support employees' efforts to produce optimal performance.

This study is consistent with previous studies such as Firer and William (2003), Chen et al (2005), Mavridis (2004), Kamath (2007), and Ulum (2008) which proved the effect of intellectual capital on financial performance and company value. The greater the intellectual capital owned by the company, the more the company opportunity to obtain value added so that it could improve company performance and had implications for increasing the company value. The results of the path analysis test showed that the effect of intellectual capital on company value was mediated by financial performance. Financial performance was also found to mediate the relationship between competitive advantage and company value.

\section{CONCLUSIONS}

This study observed the mediating impact of competitive advantage and financial performance on the relationship between intellectual capital and financial performance among banking industries. This study aims to find out whether there is an effect of intellectual capital on company value through competitive advantage and financial performance. The test results showed that the value added of Intellectual Capital (VAIC) had an effect on the company value. Company value was also influenced by competitive advantage and financial performance.

The study results obtained an empirical evidence of the mediating effect of financial performance in the relationship between intellectual capital and company value. The indirect effect of the effect of intellectual capital on company value through financial performance exceed its direct influence. Financial performance was also found to have a mediating effect on the relationship between competitive advantage and company value. However, the test results showed that the mediating effect of competitive advantage on the relationship between intellectual capital and company value was less than the indirect effect. The conclusion from the test results proved that companies that utilized intellectual capital and had competitive advantages affected financial performance and it had implications for the company value.

The author is aware of the limitations in this study. Assessments using secondary data for the competitive advantage variable might not comprehensively capture the issue of competitive advantage. The sample size used was only $58 \%$ of the population, thus it reduced the strength of the argumentation and generalization of the study results. Recomemndation for further study is to should more explore the assessment of competitive advantage variable. To find out the effect of competitive advantage, in addition to using secondary data, questionnaires or interviews can also be applied as conducted in the Kamukama study (2011). Further study should also expand the time period of observation and expand the number of samples.

\section{Reference}

Abdolmohammadi, Mohammad J. 1999. "The Components of Modal Intelektual for Accounting Measurement". Diakses di http://www.sbaer.lka.edu/research/1999/wdsi/99wds.024.html

Accounting Principles Board. 1970. Intangible Assets, APB Opinion 17. American Institute of Certified Public Accountants. New York: NY.

Accounting Standards Board. 1997. Goodwill and Intangible Assets, FRS 10. Accounting Standards Board. London. 
Bank Indonesia. 2013. Peraturan Bank Indonesia No 15/12/PBI/2013 tentang Kewajiban Penyediaan Modal Minimum Bank Umum. (www.bi.go.id) diakses tanggal 18 januari 2017.

Barney, J. 1991. Firm Resources and Sustained Keunggulan kompetitif. Journal of Management. Vol. 17 (1); 99-120.

Barney, J. B., and Clark, D.N. 2007. Resource-Based Theory: Creating and Sustaining Keunggulan kompetitif. New York: Oxford University Press. Inc.

Baron, R.M. and Kenny, D.A. 1986. The moderator-mediator variables distinction in social psycological research: conceptual, strategic and statistical considerations. Journal of Personality and Social Psychology. Vol. 51 (6); 117382.

Belkaoui, Ahmed Riahi. 2003 Modal Intelektual and Firm Performance of US Multinational Firms: a Study of The Resource-Based and Stakeholder Views. Journal of Modal Intelektual. Vol. 4 (2); 215-226.

Benoit, Kenneth. 2011. Linear Regression Models with Logarithmic Transformations. Methodology Institute, London School of Economics.

Bharadwaj, Sundar G., Varadarajan, P Rajan, dan Fahy, John. 1993. Sustainable Keunggulan kompetitif in Service Industries: A Conceptual Model and Research Proposition. Journal of Marketing. Vol. 57 (4); 83.

Bharadwaj, Sundar G., Varadarajan, P Rajan., dan Fahy, John.1993. “Sustainable Keunggulan kompetitif in Service Industries: A Conceptual Model and Research Proposition". Journal of Marketing. Vol. 57 (4); 83-84.

Bontis, N. 1998. Modal Intelektual: An Exploratory Study that Develops Measures and Models. Journal of Modal Intelektual. Vol. 36 (2); 63-76.

Bontis, N., Keow, W. C., and Richardson, S. 2000. Modal Intelektual and Business Perfor-mance in Malaysian Industries. Journal of Modal Intelektual. Vol. 1 (1); 85-100.

Brinker, Barry. 2000. Modal Intelektual: Tomorrows Asset, Today's Challenge.

http://www.cpavision.org/vision/wpaper05b.cfm.

Chen, M.C., S.J. Cheng, Y. Hwang. 2005. An Empirical Investigation of the Relationship Between Modal Intelektual and Firms' Market Value and Financial Performance. Journal of Modal Intelektual. Vol. 6 (2); 159-176.

Edvinsson, L. 1996. Measuring Modal Intelektual at Skandia. Long Range Planning. Vol. 30 (3); 266-373.

Edvinsson, L. and Malone, M. 1997. Modal Intelektual: Realizing Your Company's True Value by Finding Its Hidden Brainpower. HarperCollins. New York; NY.

Firer, S., and S.M. Williams. 2003. Modal Intelektual and Traditional Measures of Corporate Performance. Journal of Modal Intelektual. Vol. 4 (3); 348- 360.

Ghosh, S. and Mondal, A. 2009. Indian Software and Pharmaceutical Sector Modal Intelektual and Financial Performance. Journal of Modal Intelektual. Vol. 10 (3); 369-88.

Hong, Pew, Tan., David Plowman dan Phil Hancock. 2007. Modal Intelektual and Financial Return of Companies. Journal of Modal Intelektual. Vol 3, No.1, 51-61

Ikatan Akuntan Indonesia. 2007. Standar Akuntansi Keuangan . Edisi 2007. Penerbit : Salemba Empat. Jakarta . Harahap, Sofyan Syafri.

Ikatan Akuntan Indonesia. 2009. Standar Akuntansi Keuangan. Jakarta: Salemba Empat

Ikatan Akuntansi Indonesia. 2009. Standar Akuntansi Keuangan (PSAK) No. 9: Aktiva Tidak Berwujud. Jakarta : Salemba Empat.

International Federation of Accountants. 1998. The Measurement and Management of Modal Intelektual: An Introduction, New York.

Kamath, G.B. 2007. The Modal Intelektual Performance of Indian Banking Sector. Journal of Modal Intelektual. Vol. 8 (1); 96-123.

Kamukama, N., Ahiauzu, A., dan Ntayi, J.M. 2011. Keunggulan kompetitif: Mediator of Modal Intelektual and Performance. Journal of Modal Intelektual. Vol. 12 (1); 152-164.

Komnenic, B., and Pokrajcic, D. 2012. Modal Intelektual and Corporate Performance of MNCs in Serbia. Journal of Modal Intelektual. Vol. 13; 106-119.

Kubo, I., dan A. Saka. 2002. An Inquairy Into the Motivations of Knowledge Workers in the Japanese Financial Industry. Journal of Knowledge Management. Vol. 6 No. 3. pp. 262-271. 
Lin, C. and Huang, C. 2011. Measuring Keunggulan kompetitif with an Asset-Light Valuation Model. African Journal of Business Mana-gement. Vol. 5 (13); 5100-5108.

Malone, Michael S. 1997. New Metrics For A New Age: Two Experts Want This In Your Next Annual Report. Forbes ASAP. Page 40-41.

Mavridis, D.G. 2004. The Modal Intelektual Performance of The Japanese Banking Sector. Journal of Modal Intelektual. Vol. 5 (3); 92-115.

Mondal, Amitava dan Santanu Kumar Ghosh (2012). Modal Intelektual and Financial Performance of Indian Banks. Journal of Modal Intelektual. Vol. 13 (4); 515-530.

Nothnagel, K. 2008. Empirical research within resource-based theory: A meta-analysis of the central propositions. Springer Science \& Business Media.

(diakses 18 januari 2017).

Petty, P., dan J. Guthrie. 2000. Modal Intelektual Literature Review: Measurement, Reporting and Management. Journal of Modal Intelektual. Vol. 1 (2); 155-75.

Porter, M.E. 1980. Competitive Strategy: Techniques for Analyzing Industries and Competitors. New York: The Free Press

Pramelasari, Y.M. 2010. Pengaruh Modal Intelektual Terhadap Nilai Pasar dan Kinerja Keuangan Perusahaan. Universitas Diponegoro. Semarang.

Pulic, A. 1998. Measuring the Performance of Intellectual Potential in Knowledge Economy. Paper presented at the 2nd McMaster Word Congress on Measuring and Managing Modal Intelektual by the Austrian Team for Intellectual Potential.

Pulic, A. 1999. Basic Information on VAICTM. Available online at: $\underline{\text { www.vaic-on.net }}$

Rodrigues, H.S, at al. 2011. The Main Modal Intelektual Components that are Relevant to the Product, Proses and Management Firm Innovaniveness. Transitions and Innovation System. Vol. 1 (3); 271-301

Roos, J., Roos, G., Dragonetti, N. and Edvonsson, L. 1997. Modal Intelektual: Navigating in the New Business Landscape. New York University Press. New York, NY.

Sawarjuwono, T., dan A.P. Kadir. 2003. Modal Intelektual: Perlakuan, Pengukuran dan Pelaporan. Jurnal Akuntansi dan Keuangan. Vol. 5 (1); 31-57.

Starovic, D. \& Marr, B. 2003. Understanding Corporate Value: Managing and Reporting Modal Intelektual. Chartered Institute of Management Accountants.

Stewart, T.A. 1997. Modal Intelektual: The Wealth of New Organisations. Bantam Doubleday Dell Publishing Group. Ney York. NY

Ulum, Ihyaul M.D. 2008. Modal Intelektual Performance Sektor Perbankan di Indonesia. Jurnal Akuntansi dan Keuangan. Vol. 10 (2);77-84.

Untara, Andini Pemata, Titik Mildawati. 2014. Pengaruh Modal Intelektual Terhadap Kinerja Keuangan Perusahaan Perbankan yang Terdaftar di BEI. Jurnal Ilmu \& Riset Akuntansi. Vol. 3 (10).

Vergauwen, P., L. Bollen, dan Els, Oirbans. 2007. Modal Intelektual Disclosure and Intangible Value Drivers: an Empirical Study. Management Decision. Vol. 45 (7); 1163-1180.

Woodcock, J., and Whiting, R.H. 2011. Firm characteristics and Modal Intelektual disclosure by Australian companies. Journal of Human Resource Costing \& Accounting. Vol. 15 (2); 102 - 126.

Zeghal, D. And Maaloul, A. 2010. Analysing value added as an indicator of Modal Intelektual and its consequences on company performance. Journal of Modal Intelektual. Vol. 11 (1); 39-60. 